\title{
Hausmannian Buildings Rehabilitation and Strengthening
}

\author{
Rui Cardoso ${ }^{1}$, Anabela Paiva ${ }^{2}$, Jorge Pinto ${ }^{2}$, and João Carlos Gonçalves \\ Lanzinha $^{1}$ \\ ${ }^{1}$ Beira Interior University \\ ${ }^{2}$ Universidade de Trás os Montes e Alto Douro
}

\section{Abstract}

Hausmannian buildings architecture spreads throughout the city of Paris. These buildings were constructed in the 19th century, being presently centenarians. However, they present several pathologies which prevent their adequate use, moreover, an update regarding users security, sound, thermal and fire requirements is, among others, urgently needed. Additionally, there is presently, in Paris, an increasing demand for hotel rooms. For those previous reasons, Hausmannian buildings are presently submitted to heavy operations related to rehabilitation, strengthening, use change and conservation. In this paper, rehabilitation and strengthening works presently carried

Corresponding Author:

Rui Cardoso

rui.cardoso@ubi.pt

Received: 26 November 2019

Accepted: 13 May 2020

Published: 2 June 2020

Publishing services provided by Knowledge E

(c) Rui Cardoso et al. This article is distributed under the terms of the Creative Commons

Attribution License, which permits unrestricted use and redistribution provided that the original author and source are credited.

Selection and Peer-review under the responsibility of the ICEUBI2019 Conference Committee.

\section{G OPEN ACCESS}

out in those buildings are described. This description is the result of a technical survey on several Hausmannian building construction sites which occurred between 2015 and 2018. The knowledge from this study should be very useful for the development of sustainable rehabilitation and strengthening techniques and guidelines, aiming to preserve this important building heritage or similar ones existing in other countries.

Keywords: Hausmannian buildings, Rehabilitation, Strengthening, Sustainability

\section{Introduction}

A huge quantity of rehabilitation and strengthening works have been carried out in Paris Hausmannian buildings. These buildings, being old, since many years have passed since they were built or rebuilt, around the 19th century, present a very poor state of conservation and the structure shows a widespread presence of defects resulting from the deterioration of the materials. Moreover, the environmental issue related to energy consumption for cooling and heating make them obsolete, as the lake of insulation of the facades and roofs. Beyond that, Hausmannian buildings are representative of the Paris' architecture [1-6], since all the city is based on that architecture, which had been used before concrete and steel started to be used in the 20th century. In addition, there is a huge demand for hotel rooms in the city of Paris due to a growing tourism activity. All the reasons previously presented justify the urgent need to carry out rehabilitation and strengthening works, since It is of vital importance to preserve 
and protect this legacy and demolition can't be a solution. This scenario, related to traditional building heritage state of conservation is not unique and can be found in several European countries, [7-14]. This article describes the main rehabilitation and strengthening works presently carried out on Hausmannian buildings located in Paris and is based on information gathered on site between 2015 and 2017. This paper is original because it results from site construction surveys realized during rehabilitation working stages, by the first author, which was simultaneously the strengthening project designer. Proper investigations were carried out in the superstructure and on the foundations and several photographs are included. The authors strongly believe this paper will allow research studies related to rehabilitation and strengthening techniques in old and historic buildings, as the development of sustainable innovating rehabilitation and strengthening techniques, [15]. The paper organization is the following: firstly Hausmannian buildings are characterized; secondly, rehabilitation and strengthening works are described. Finally, some conclusions are drawn.

\section{Hausmannian Buildings Description}

Hausmannian building were built between 1830 and 1841. These buildings have usually 6 or 7 stories. Site observations allowed to conclude that their structure is highly composite and conceived essentially with local materials, [16]. The main façades are made with $55 \mathrm{~cm}$ width dressed stone Fig. 1.

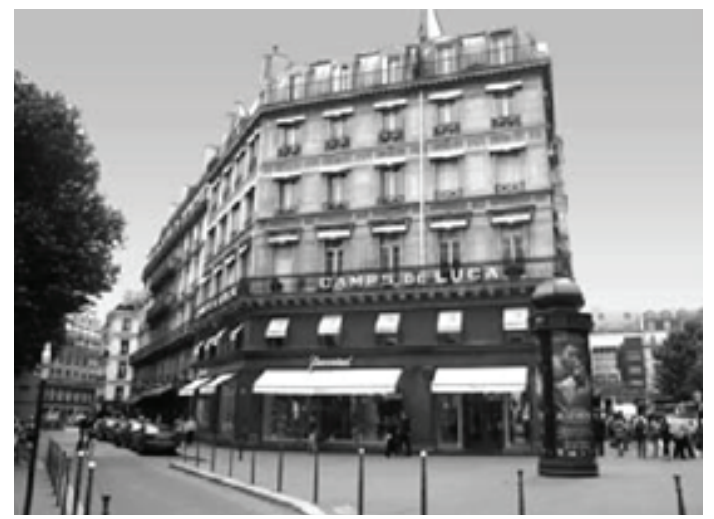

Figure 1: The Hausmannian building, La Madeleine near the Saint Marie Madeleine Church

The façades located in the backside are made with a timber frame structure filled with limestone rubble or with a steel frame structure filled with bricks. The ground floor might have a commercial use and the basement floor is used as a storage and to the technical equipment. The uppers floors are used for office purposes or housing, Fig. 


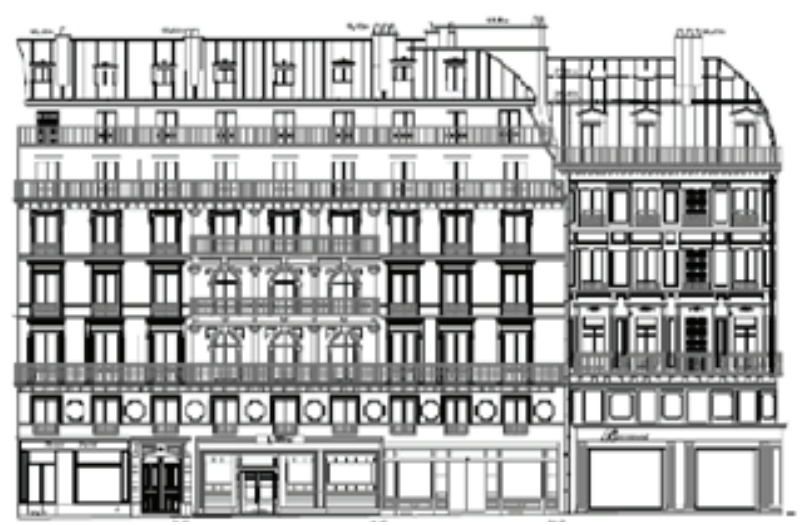

Figure 2: The Hausmannian building, front façade

2. The interior walls are made with clay bricks, Fig. 3 or a timber structure filled with limestone, Fig. 4, both of them usually load-bearing walls.

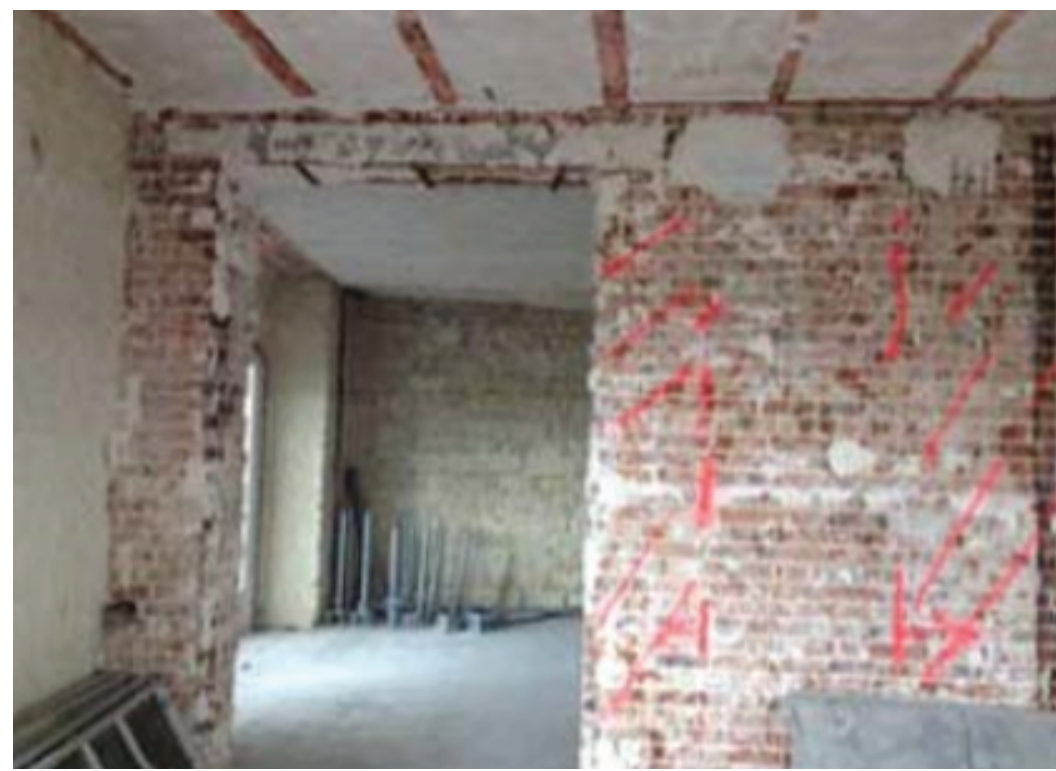

Figure 3: Interior walls, clay brick wall

Generally, the façade walls of two upper floors are also made with a timber frame solution, Fig. 5. On the ground floor level, the façades are supported by limestone rubble masonry walls located beneath them, on the basement floor and along the building perimeter, [17]. The ground-floor is supported with limestone masonry vaults and the vaults are supported by interior and perimeter limestone rubble masonry walls, Fig. 6.

On the basement floor the interior walls can be made with limestone rubble masonry or clay bricks. The interior wall thickness varies from $40 \mathrm{~cm}$ to $65 \mathrm{~cm}$ and the perimeter walls are approximately $80 \mathrm{~cm}$ thick. This had been the main structural system until concrete started to be used and since timber elements could not had been used in 


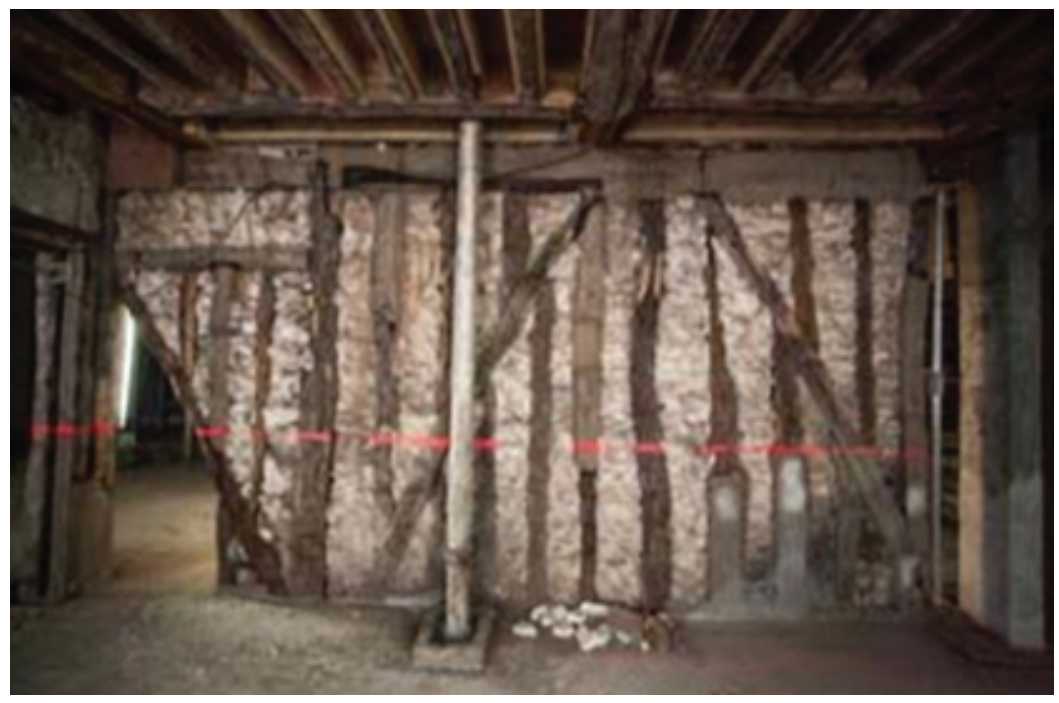

Figure 4: Interior walls, timber wall

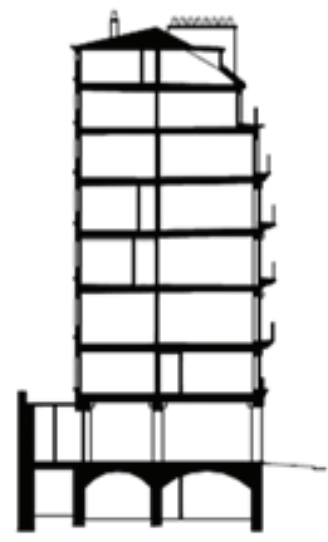

Figure 5: Hausmannian buildings structure, building cross-section elevation

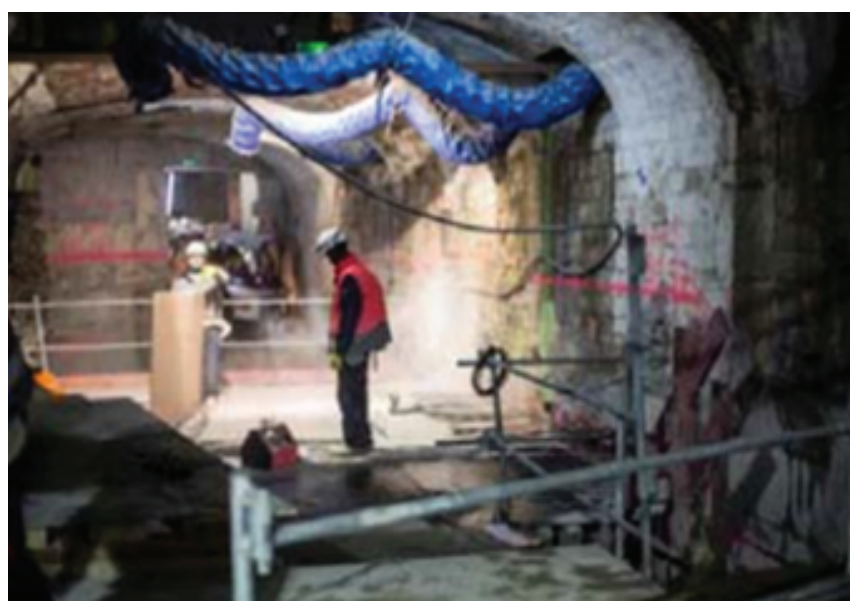

Figure 6: Hausmannian buildings structure, basement walls.

the basement due the presence of high humidity levels. The floors are normally of two types. The first type refers to floors made of a timber joist with floorboards attached to it and the second type is related to a floor system realized with a metallic joist and 
plaster interjoists. It has been observed that IAO metallic profiles are located above the 3rd floor, this distribution clearly indicates a technical evolution from timber floors to metallic floors. Foundation investigations revealed that the foundations of the existing walls are essentially realized extending downward the limestone rubble masonry walls from $15 \mathrm{~cm}$ to 1 meter below the ground. Occasionally, a concrete or limestone masonry strip footing or a limestone footing is placed beneath the walls, [17].

\section{Hausmannian Buildings Rehabilitation and Strengthen- ing Works}

The construction site survey carried out has indicated that rehabilitation and strengthening works being realized in Hausmannian buildings consist in strengthening the existing floors or pouring new concrete floors, adding one or two new basement floors, removing complete interior load-bearing walls or introducing openings in existing interior walls, adding elevators, adding concrete beams, concrete columns, steel beams and steel columns. During these works some structural elements like existing floors, interior brick walls, interior timber walls, the entire Hausmannian façade, the exterior and visible part of the chimneys, are maintained and conserved, clearly indicating that it is possible to update technical characteristics regarding actual regulations with rehabilitation and strengthening works, avoiding the complete demolition of structural elements. Rehabilitation and strengthening works are presently, carried out in a sustainable manner in the building construction industry.

\subsection{Hausmannian floors rehabilitation and strengthening}

Hausmannian floor's structural systems are usually of two types. The first type refers to floors made of a timber joist with floorboards attached to it and the second type is related to a floor system realized with a metallic joist (IAO metallic profiles) and plaster interjoists. In a few Hausmannian buildings, it has been observed that IAO metallic profiles are located in the upper floors, the lower floors being realized with timber floors, this distribution clearly indicates a construction practice evolution from timber floors to metallic floors. 


\subsubsection{Timber floors description and strengthening}

The timber floor structure is made with massif oak timber beams made, under these beams laths and a mortar bears the floorboard revetment, Fig. 7, below theme and attached to it, there is the floor ceiling made with laths and plaster as shown in Fig 8 , [18].

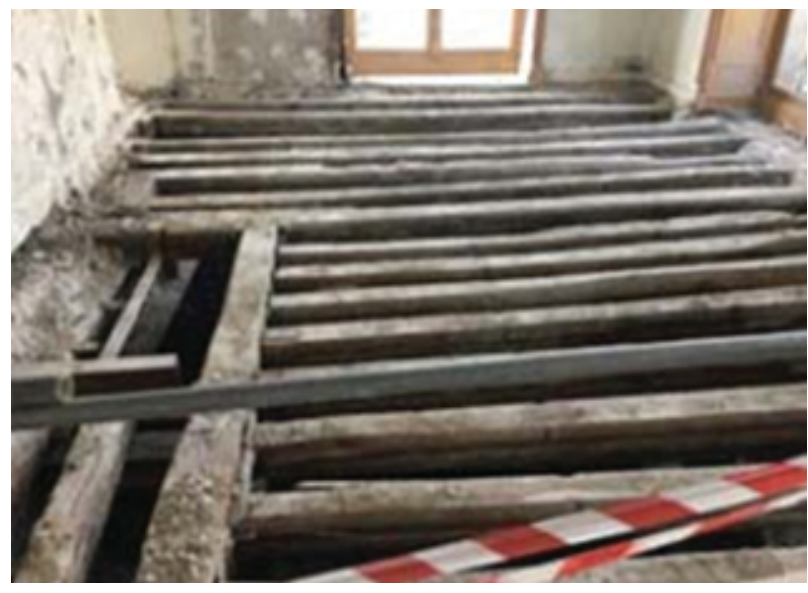

Figure 7: Timber floors,

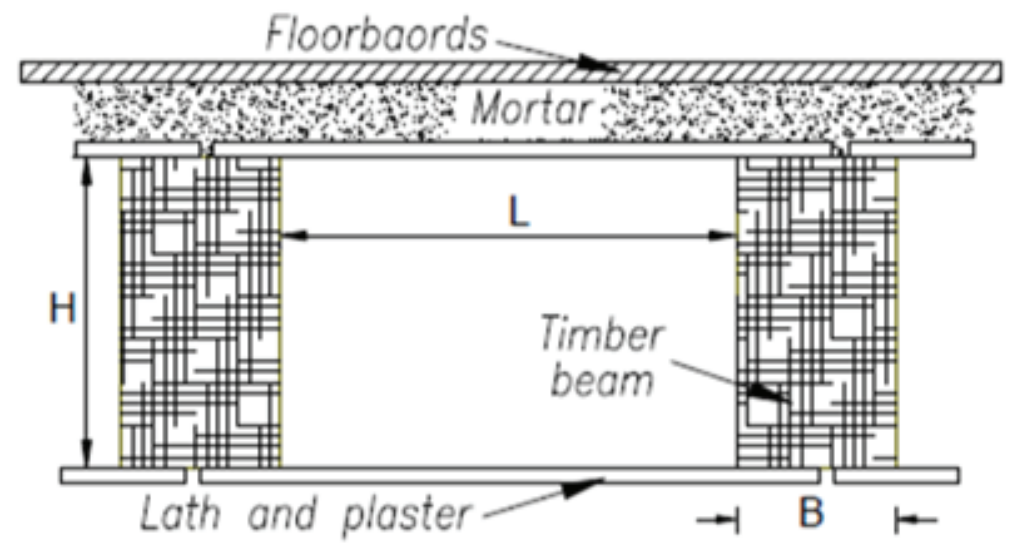

Figure 8: Timber floors, detail

The geometrical analyze of several timber floors, from several Hausmannian buildings, allow observing variation in the principal dimensions. The results indicate that the spacing (L) between beams varies from $16 \mathrm{~cm}$ to $30 \mathrm{~cm}$, the beams width (B) beams varies between $7 \mathrm{~cm}$ and $12 \mathrm{~cm}$ and can exceptionally reach $24 \mathrm{~cm}$ and finally, the beam height $(H)$ varies from $15 \mathrm{~cm}$ to $26 \mathrm{~cm}$, [19]. It is possible to verify that the timber floor joists, [19], do not have more the required resistance and stiffness to safely carry the loads. Several beams present high deformations or have extensive cracks which should have been originated by the natural decay. A weakening due to attacks by wood-eating insects and fungi is also evident, [7], [10]. Strengthening works are needed since these timber 
floors do not have the necessary load carrying capacity, but also because regarding the overall building stability they do not brace correctly the structure against possible horizontal movements of the façade. The strengthening work consists in pouring a new concrete slab under the existing timber beams. The connected concrete slab is usually $8 \mathrm{~cm}$ thick. The initial state of the timber pavement is illustrated in Fig. 9 and represented by the existing timber beams, the laths and the plaster.

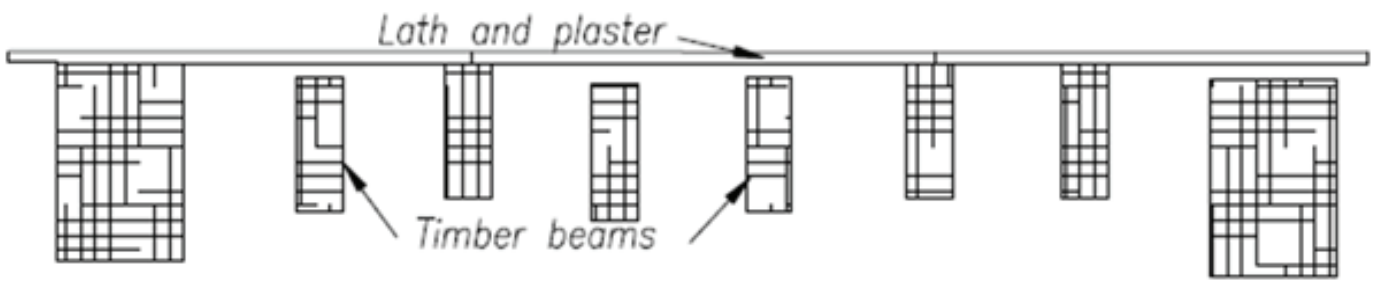

Figure 9: Timber floor - Initial state

Steel cylinders made connectors are applied on the top of the beams, their spacing and number are obtained after calculations, Fig. 10, then the reinforcement is put in place and finally the slab is poured, Fig. 11. Fig. 10. clearly shows that this technique allowed to maintain an important quantity of existing materials and therefore it can be classified as a sustainable strengthening technique. This will not have been the case, if instead, a complete $20-25 \mathrm{~cm}$ thickness traditional concrete slab should had been poured.

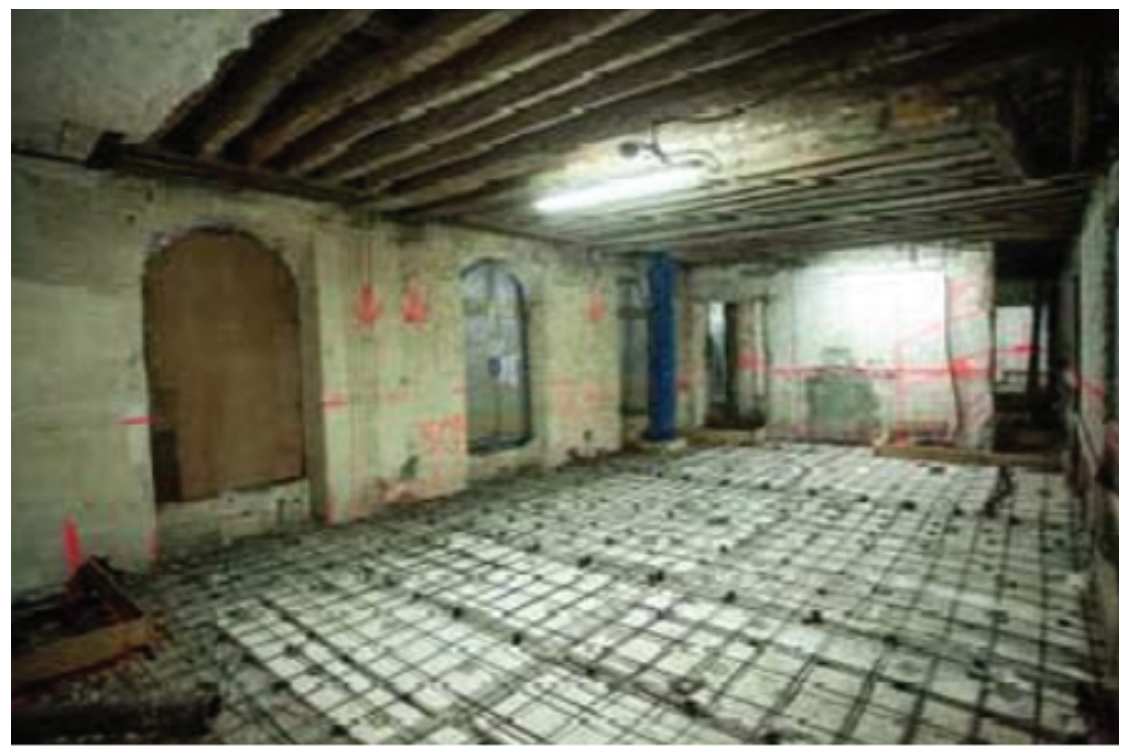

Figure 10: Strengthened timber floor, connectors and reinforcement 


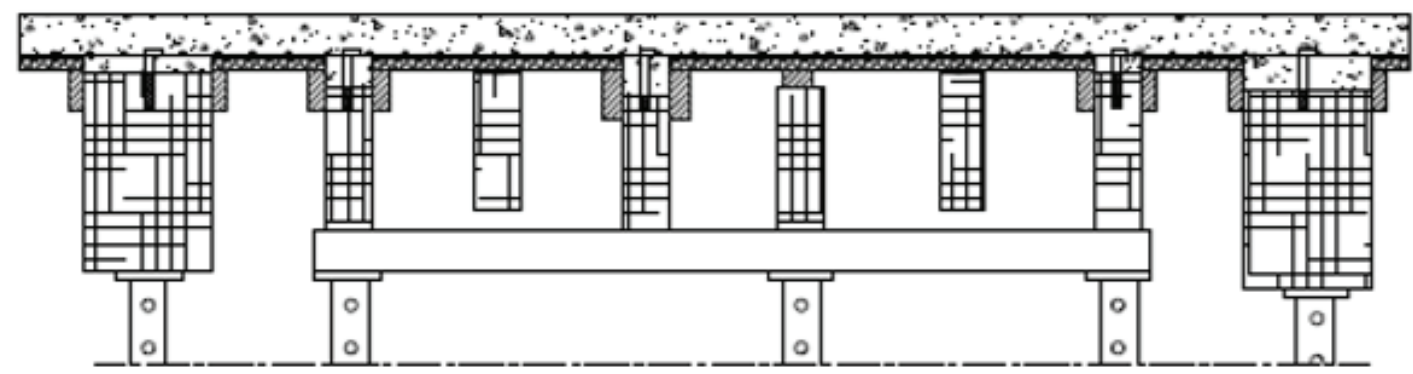

Figure 11: Strengthened timber floor, connected concrete slab

\subsubsection{Metallic floors description and strengthening}

In Hausmannian buildings, it is usual to find floors made of metallic beams constituted of IAO cross-sections, Fig. 12. Between these beams, plaster interjoist elements are set, Fig. 13. The investigation on metallic IAO profiles indicated high deflections and plaster cover deterioration. Furthermore, the design calculations indicate also that these floors do not have the necessary strength to carry the loads rising from the new regulations, [20] and due to use changes operated.

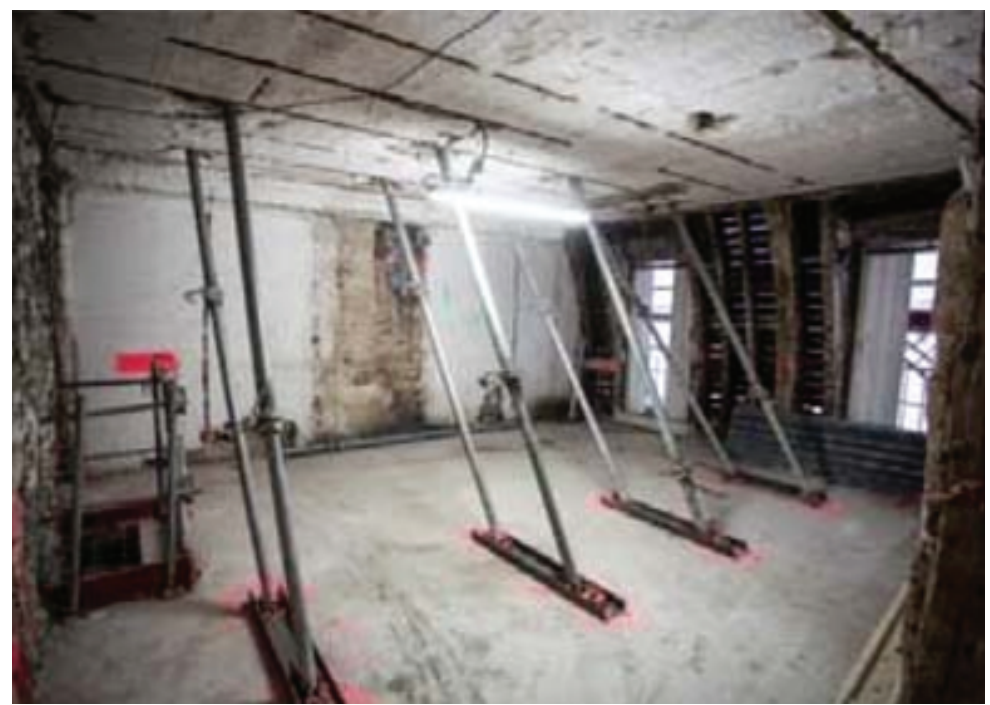

Figure 12: Metallic IAO floors

Investigation on the metallic IAO profiles allowed identifying different types of metallic floors, depending on the IAO dimensions, [18]. The strengthening technique for the existing metallic floors consists in maintaining the IAO profiles and creating a new concrete slab. Three solutions can be considered, in the first a concrete slab is connected to the metallic IAO profiles, the existing plaster interjoists are kept in place, Fig. 14 illustrates this solution. The connected concrete slab thickness can vary between 8 and $12 \mathrm{~cm}$. Hilti X-HVB steel connectors are connected to the top of the IAO profiles. 

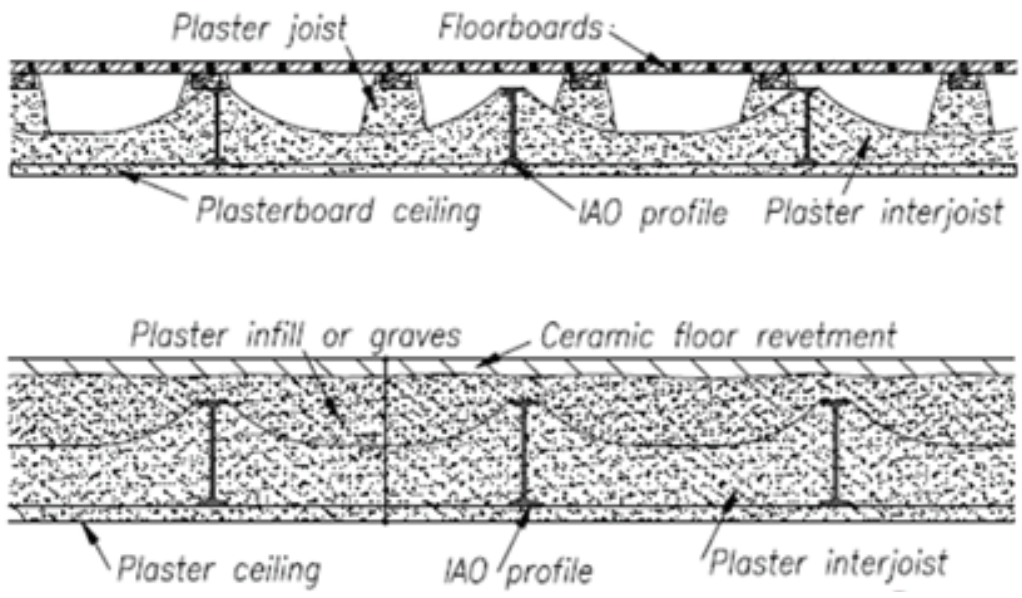

Figure 13: Metallic IAO floors, detail

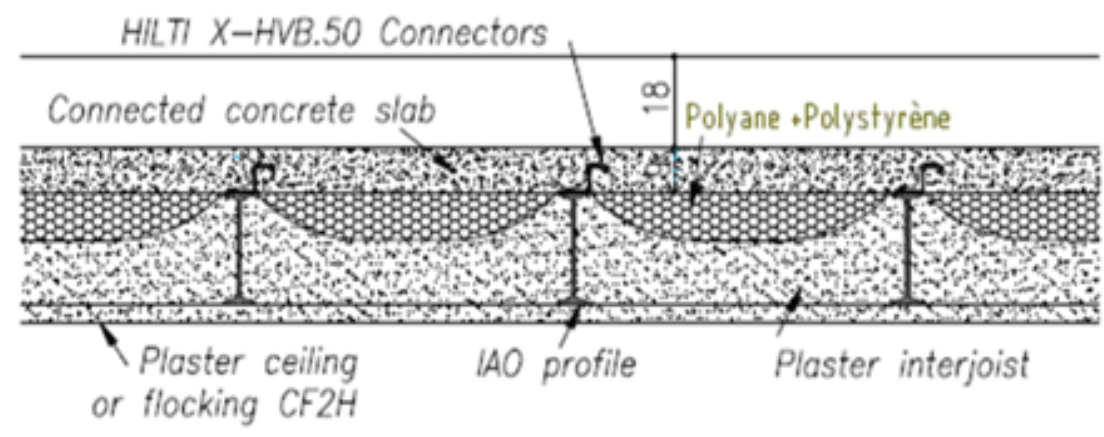

Figure 14: Connected concrete slab

\subsection{Basement creation and underpinning works}

Hausmannian building have usually only one basement, presently it is usual to increase the existing basement head height or to add one or two basement floors. One of the most commonly used techniques in Hausmannian buildings to underpin the existing foundations is concrete pouring. This technique consists in excavating the soil under the existing foundation and pouring concrete to construct a new wall and its foundation at the desired lower level, [21]. Fig. 15 illustrates the underpinning works relative to the addition of a basement floor and Fig. 16 represents the construction drawing, [22].

This technique is recommended if, simultaneously the digging depth is low, the dug soil is cohesive, there is no water level and the bearing strength of the soil under the new foundation soil is sufficiently strong to bear the new loads, which are obviously greater than the previously existing loads, [23], [24]. Fig. 17 and 18 represents the construction drawing relative to the pouring of a concrete wall beneath the existing limestone rubble masonry wall, the new concrete floor and the concrete raft. 


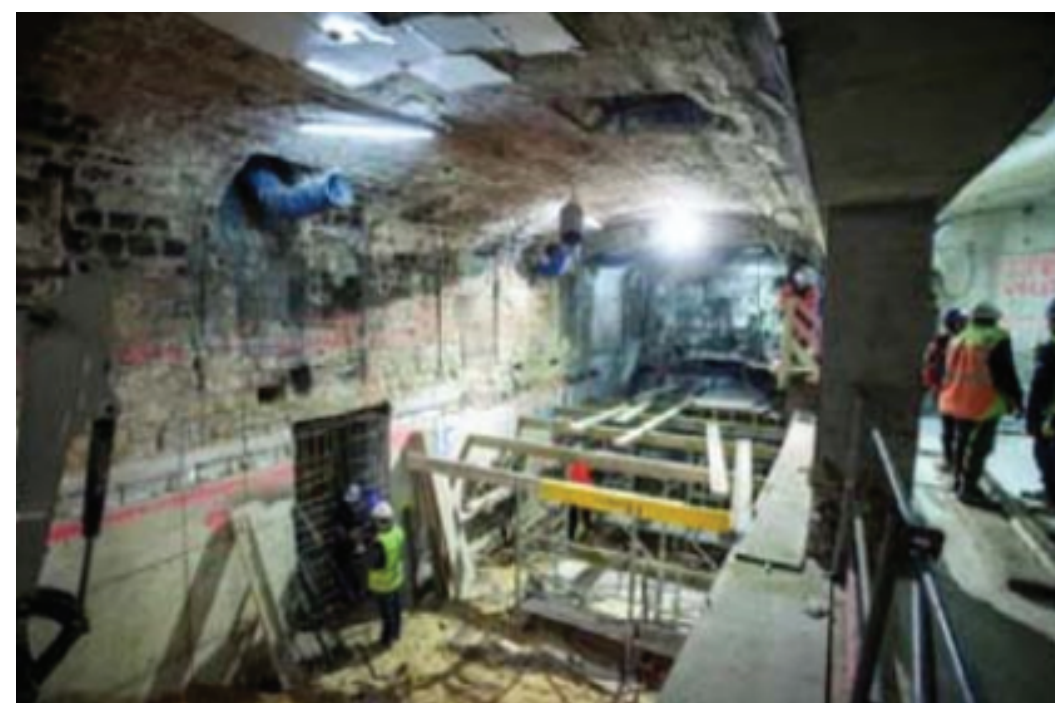

Figure 15: Basement concrete raft pouring, existing basement

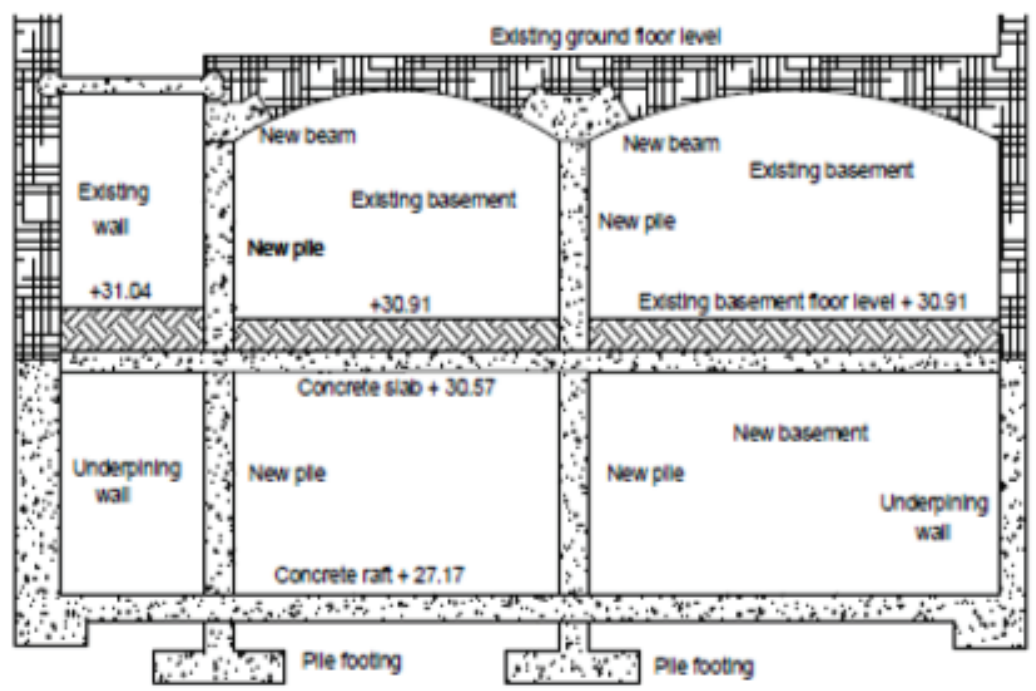

Figure 16: Basement concrete raft pouring, new basement design

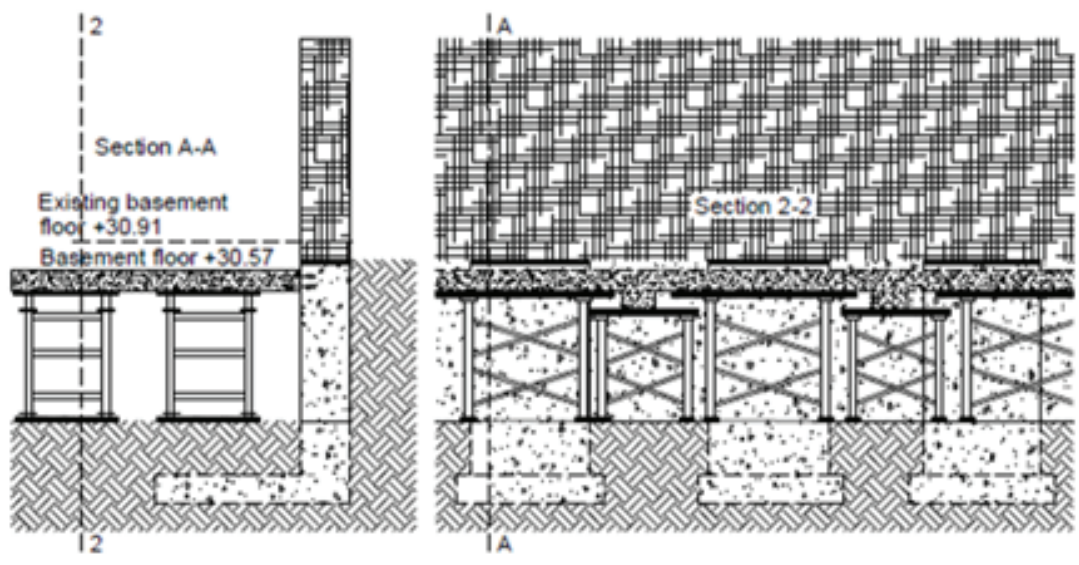

Figure 17: Floor basement pouring, slab concrete pouring 


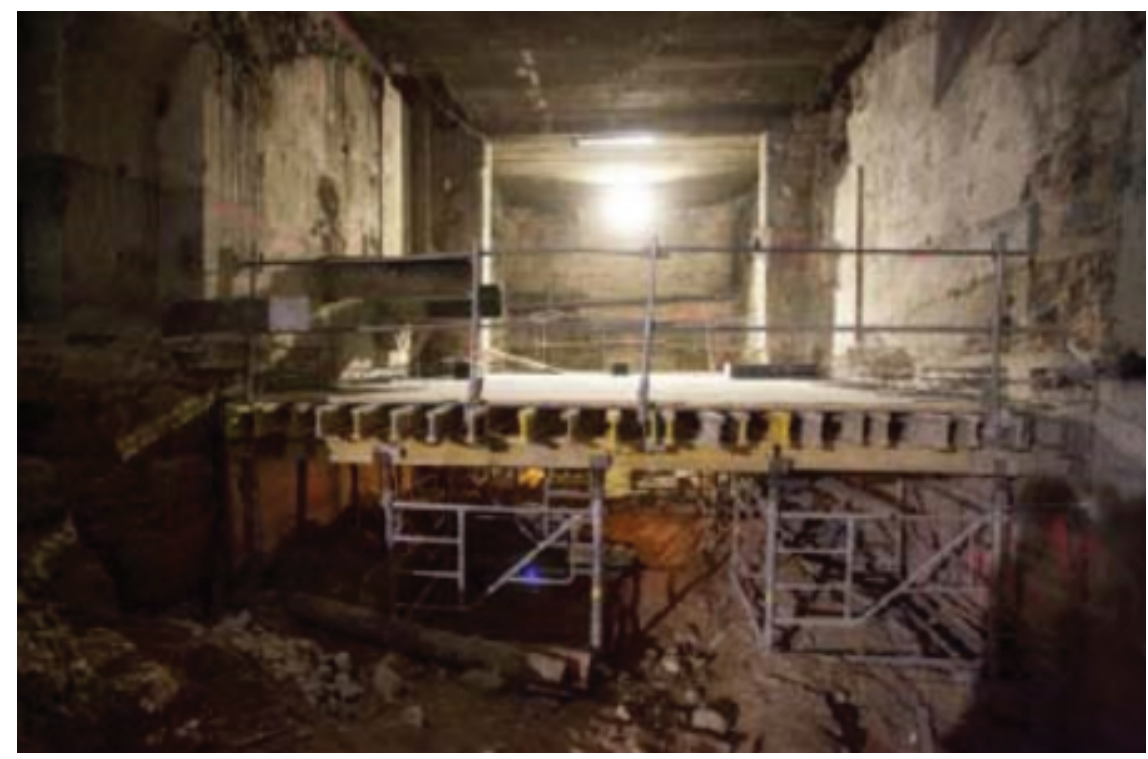

Figure 18: Floor basement pouring, slab shoring tower

Fig. 19 represents the construction drawing relative to the pouring of a concrete wall beneath the existing limestone rubble masonry wall, the new concrete floor and the concrete raft.
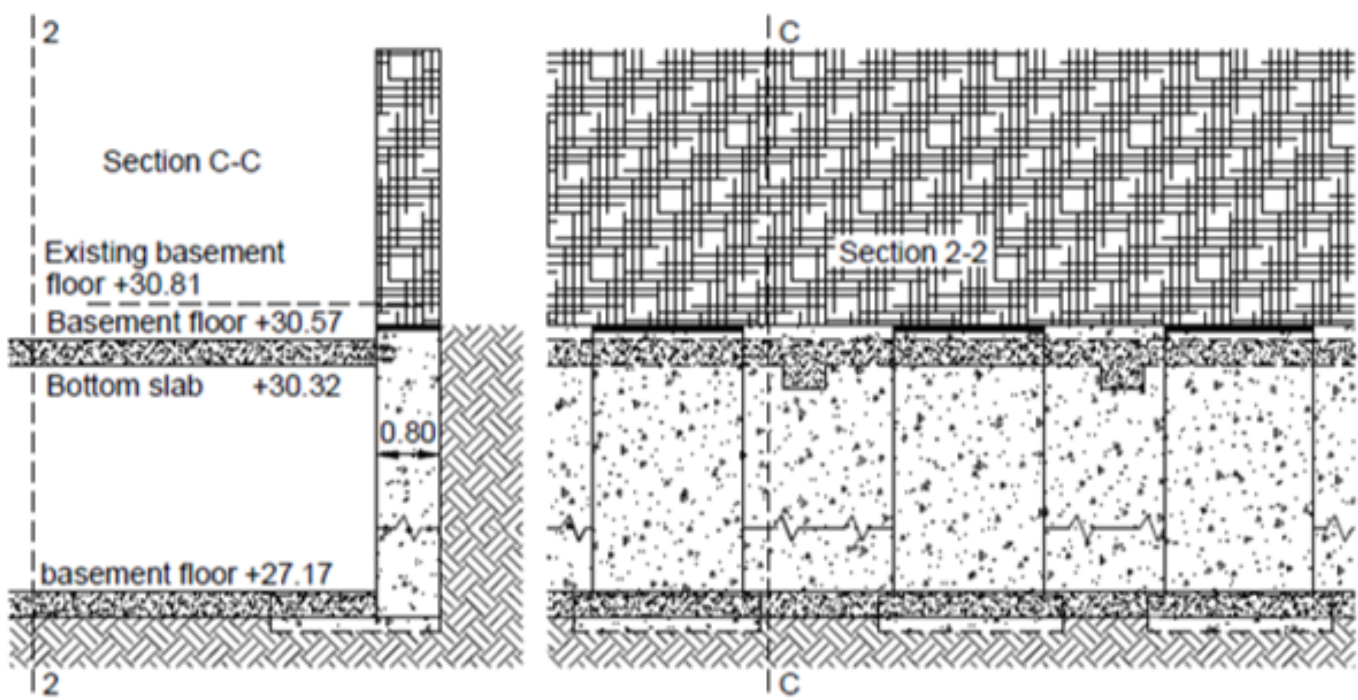

Figure 19: Basement concrete raft pouring

\subsection{Interior walls rehabilitation and strengthening}

The interior walls, made from a timber structure or made from masonry bricks are usually removed, for partition reasons, otherwise they are kept in place. In Fig. 20 a timber wall 
is kept in place but strengthened with a steel portal frame. In Fig. 21 a timber structure was removed and replaced by a concrete frame with beams and columns.

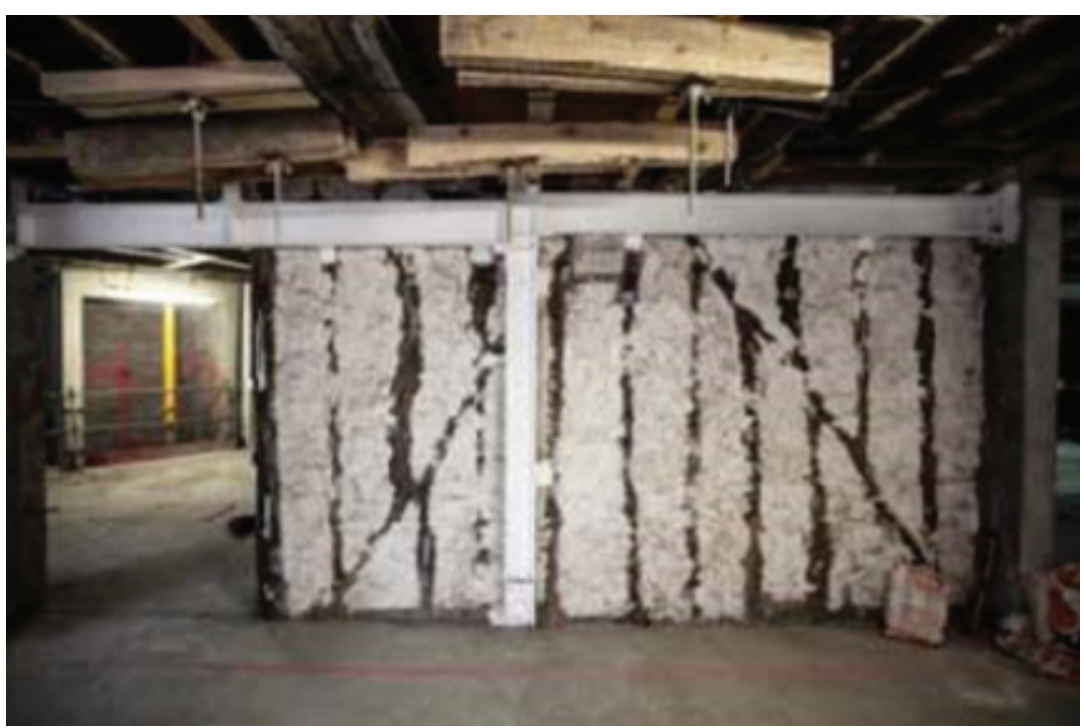

Figure 20: Timber walls rehabilitation, wall strengthening

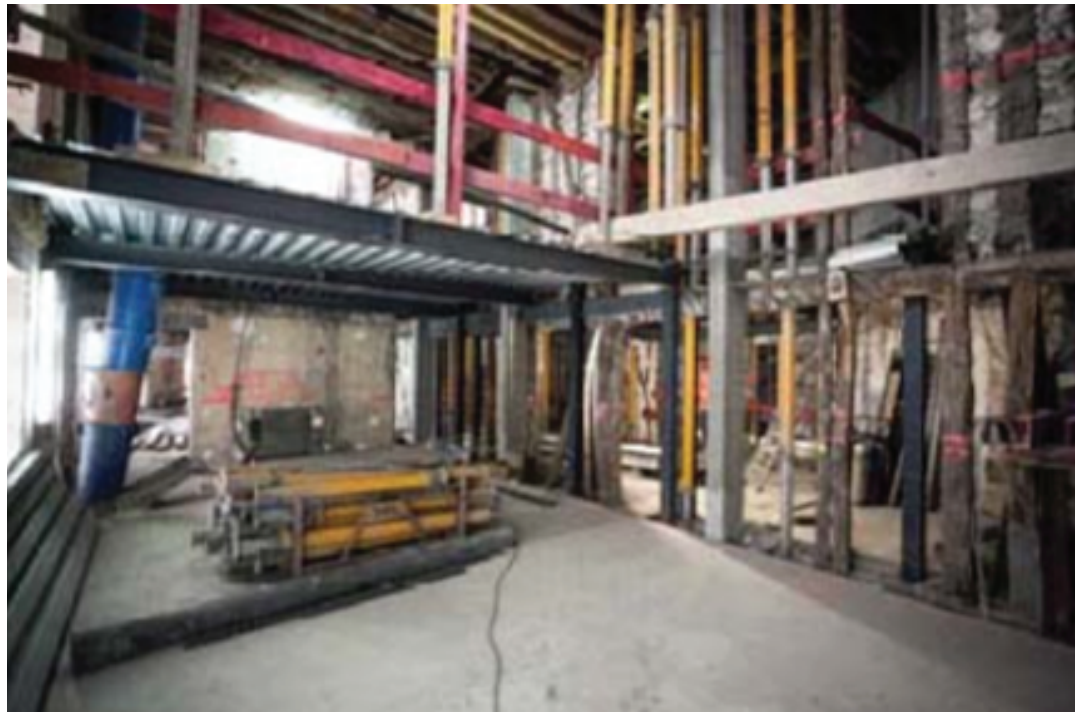

Figure 21: Timber walls rehabilitation, wall removed

\subsection{Roof rehabilitation}

The roof structure, made with timber components, is another component that is usually subjected to rehabilitation and strengthening works, since the original structure usually presents an accelerated decay due to water penetration, among others, Fig. 22.

The existing timber structure is replaced by a new timber structure or by a steel structure. In Fig. 23 it is possible to observe the attic without the roof timber structure 


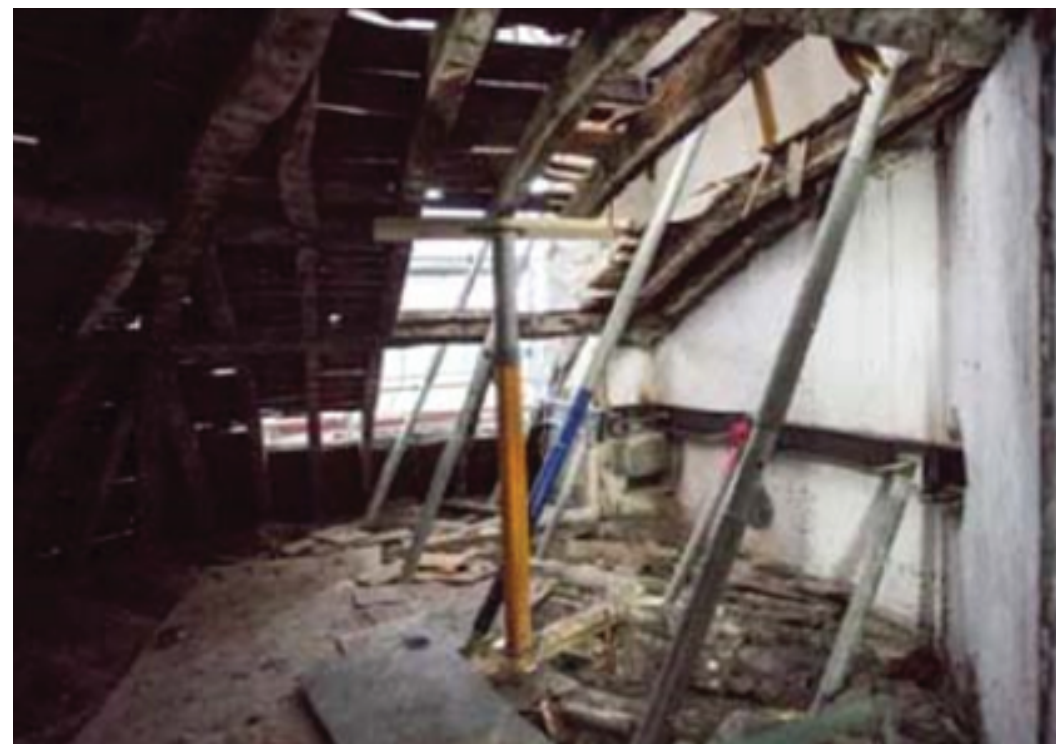

Figure 22: Existing timber roof structure

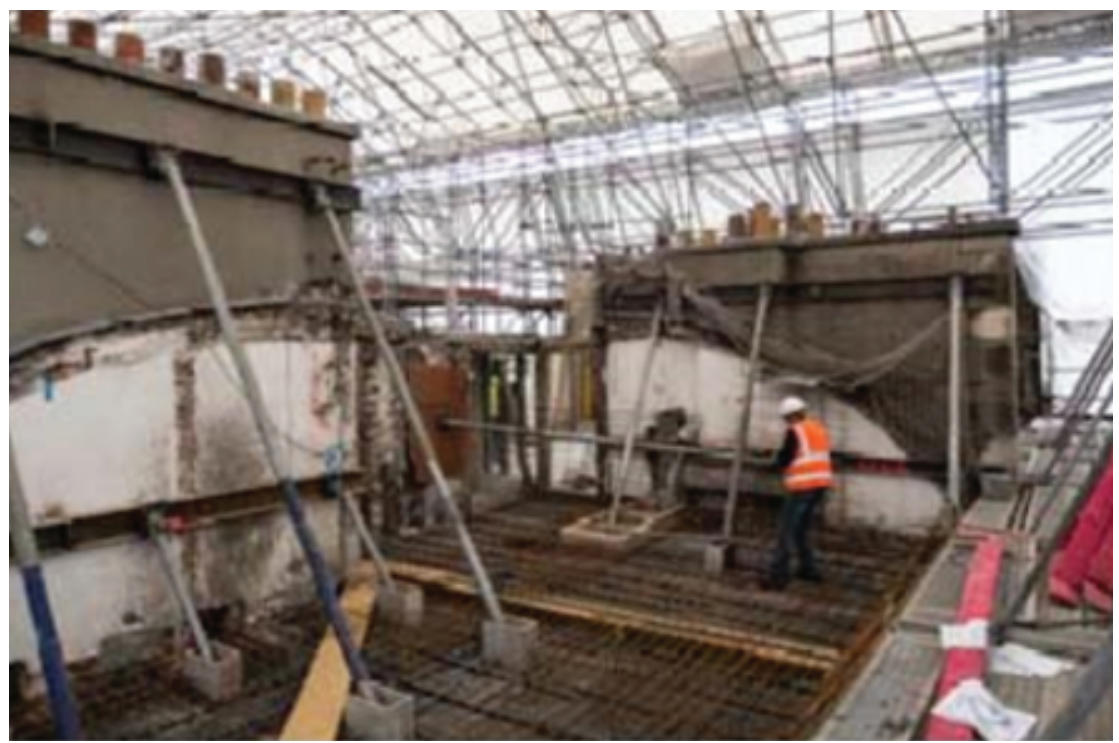

Figure 23: Existing timber roof structure, remova

and just after his removal. In Fig. 22 it is also possible to observe that the chimneys, braced by the roof had to be correctly shored with props to withstand the wing action. As stated previously, one possible way to rehabilitate the roof structure consists in the erection of a new timber structure as represented in Fig. 24 Fig. 25 illustrates a view from the inside of the timber structure.

Another possibility to rehabilitate the roof structure consists in the erection of a new structure made of steel profiles as represented in Fig. 26 and Fig. 27. 


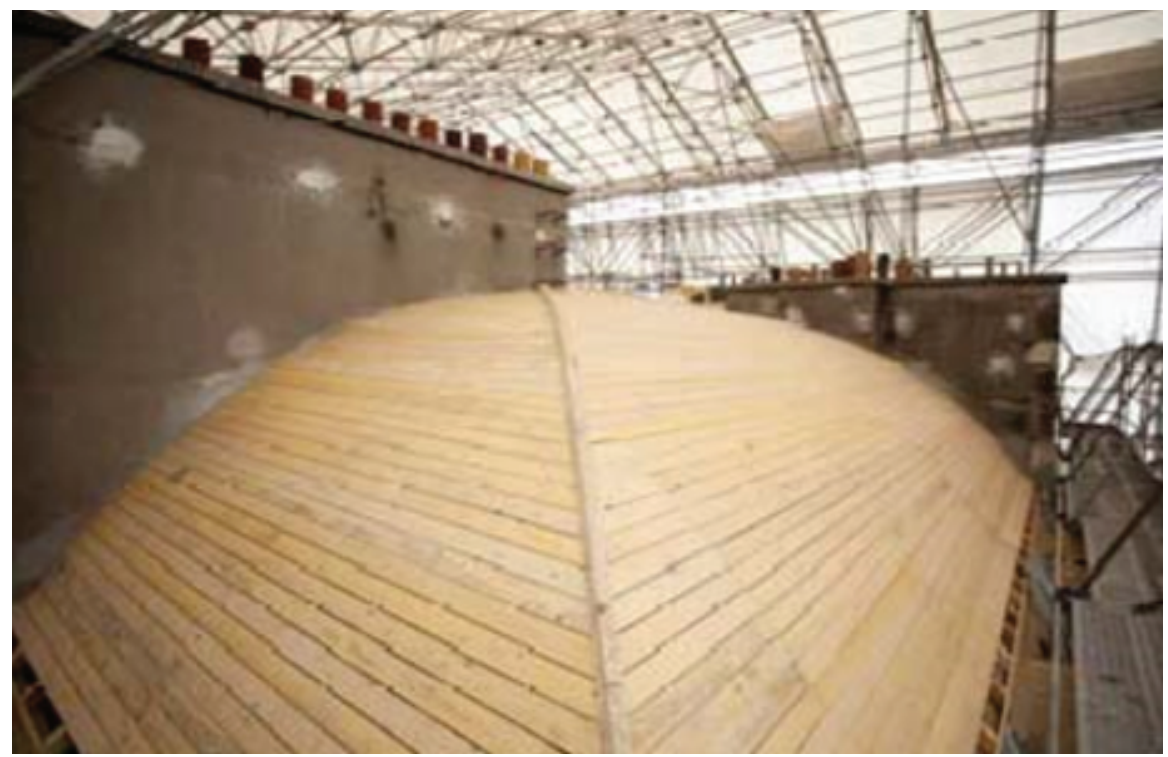

Figure 24: Roof rehabilitation, new roof timber structure

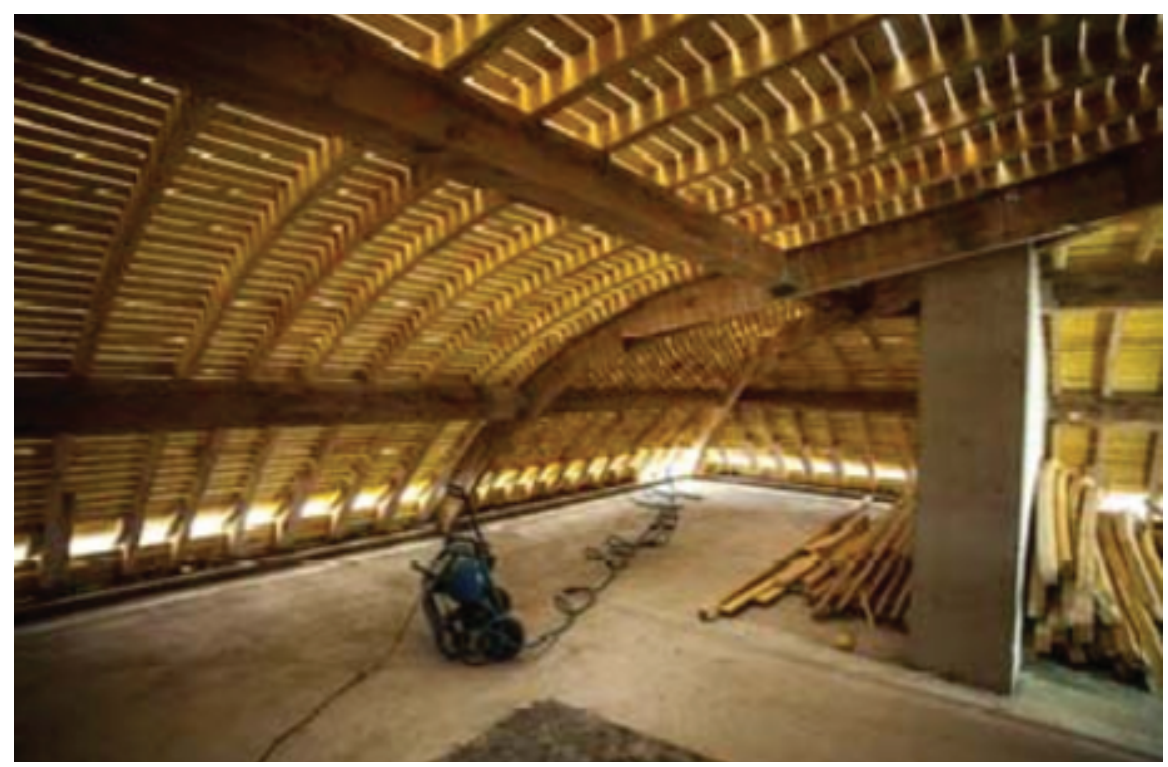

Figure 25: Roof rehabilitation, inside view

\section{Conclusions}

The investigations carried out in Hausmannian buildings during rehabilitation and strengthening works have shown that the materials used are: stone; limestone rubble; wood; plaster; steel and cast-iron corresponding to a predominant use of raw and local materials. Five solutions were found for the walls, which are: a timber frame with limestone infill, a metallic frame with brick infill, brick masonry, dressed stone and limestone rubble masonry. The floors are made with timber joists or metallic IAO profiles. The foundations are essentially obtained by extending the basement walls 


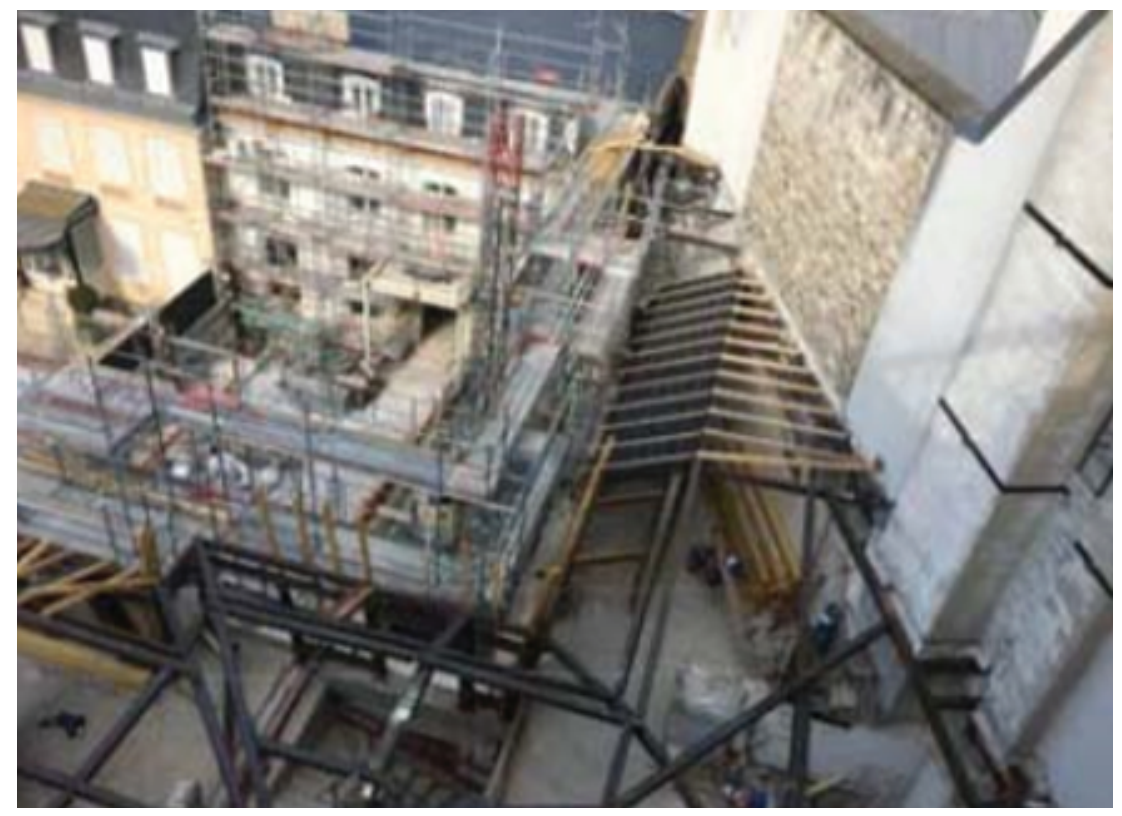

Figure 26: Roof rehabilitation, roof structure erection

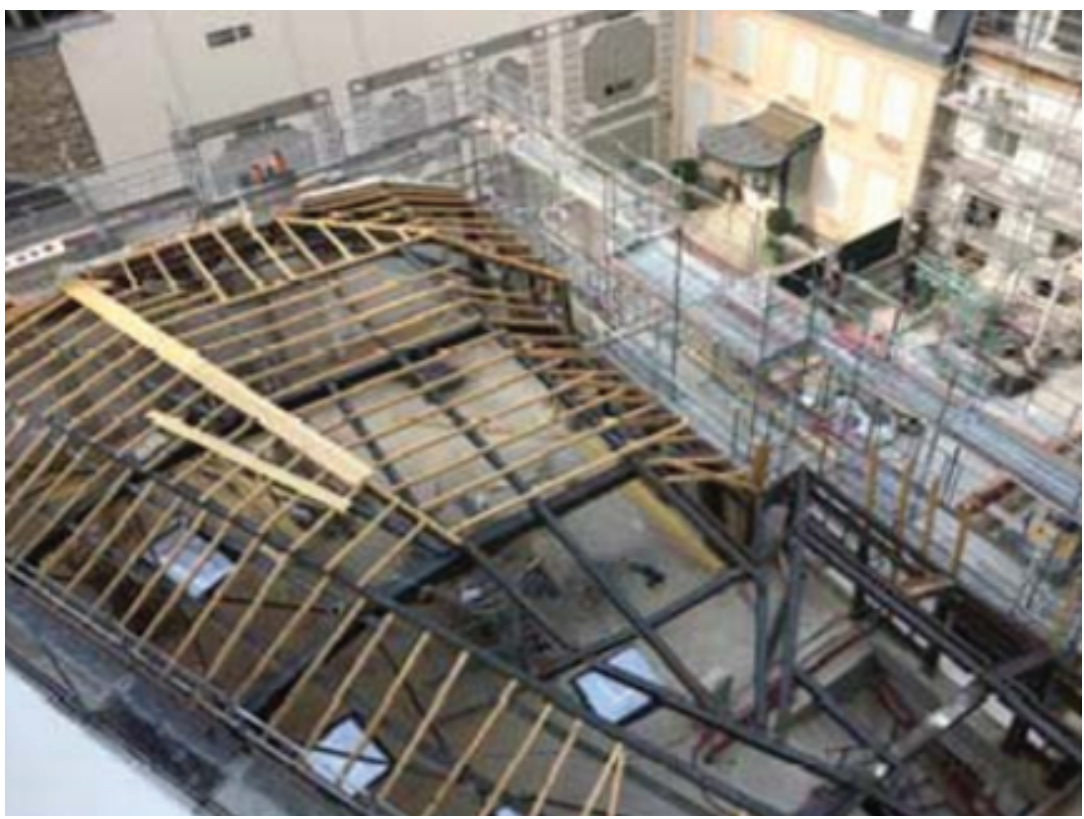

Figure 27: Roof rehabilitation, roof timber components

under the ground and sometimes a strip footing could be observed. Several limestone rubble masonry vaults are located on the basement, these vaults support the ground floor level. The building resistant structure is very simple, with the structural loadbearing elements aligned along vertical lines. The investigations allowed also to verify that this building complex is very damaged by the normal material decay. Deformations and cracks are visible in the floors, in the timber stairs, on the walls and there is water infiltration in the basement. The rehabilitation and strengthening works carried out in the floors intended, among others, to eliminate the existing pathologies and increase their 
strength and stiffness. The strengthening technique for the floors is essentially based on pouring a concrete slab connected to the timber joists or to the IAO profiles. This is, at the present time, a traditional technique in Paris old and historic building rehabilitation. This strengthening technique fulfills the actual requirements in terms of structural integrity, fire safety, thermal and soundproof insulation. Moreover, since it retains a great amount of the original structure and minimizes the intervention and the introduction of new elements it should be cataloged as a sustainable strengthening technique. The underpinning operation described allowed to create a new basement level in a topdown construction methodology. This underpinning technique, adequate for shallow depth foundations is largely used actually in Hausmannian building rehabilitation. In addition to skilled labor, this kind of project also requires a precise planning stage as well as a rigorous designing stage since a large quantity of hard work and multiple steps are needed and there is not a universal solution applicable to all cases. Interior walls and roofs are structural components that are also subjected to rehabilitation and strengthening techniques, the walls can be strengthened with metallic profiles and the existing roofs are usually removed and replaced either by a timber structure or a metallic one. The demand for rehabilitation and strengthening has increased in the last years as old buildings renewals and refurbishment has gained popularity, mainly in the European oldest cities. The knowledge presented in this paper is intended to give guidelines to practicing engineers and contractors of other regions, to support the development of innovating and sustainable strengthening techniques but also to give guidance to numerical and experimental research related to strengthening and rehabilitation. Rehabilitation and strengthening techniques play a very important role in the global sustainable development of cities, therefore their planning and design stage should be realized carefully and rigorously.

\section{References}

[1] Froidevaux Y. (1986). Techniques de l'architecture ancienne: construction et restauration. Brussels: Pierre Mardaga.

[2] Jomber C. (1764). Modern Architecture or the good construction art for all types of persons Paris.

[3] Jordan D.P. (2004). Haussmann and Haussmannisation: The legacy for Paris. French Historical Studies vol. 27, issue 1, pp. 87-112.

[4] Jordan D.P. (2015). Paris Haussmann and after. Journal of Urban History vol. 41, issue 3, pp. 541-549. 
[5] Keegan E., Meffre R., and Marchand Y. (2017). Haussmann stories Paris chartiercorbasson architects. Architect, vol. 106, issue 7, pp. 147-151.

[6] Lepoutre D. (2010). History of a Haussmann-design apartment building in Paris: Inhabitant categories and intra-building relations in a bourgeois milieu. Revue Francaise de Sociologie, vol. 51, issue 2, pp.321-358.

[7] Branco J.M., Piazza M., and Cruz P.J.S. (2011). Experimental evaluation of different strengthening techniques of traditional timber connections. Engineering Structures, volume 33, issue 8, pp. 2259-2270.

[8] Tavares A., D’Ayala D., and Costa A. et al. (2014). Construction Systems, in Structural in: Costa A., Guedes J., Varum H. (eds) Rehabilitation of Old Buildings. Building Pathology and Rehabilitation. Berlin: Springer.

[9] Branco J.M. and Tomasi R. (2014) Analysis and Strengthening of Timber Floors and Roofs, in: Costa A., Guedes J., Varum H. (eds) Rehabilitation of Old Buildings. Building Pathology and Rehabilitation. Berlin: Springer.

[10] Cardoso R. (2013). Tabique Construction Characterization in Lamego and Alto Douro/ PhD dissertation, Beira Interior University, Portugal.

[11] Cardoso R., Paiva A., Pinto J., et al. (2011). Building details of a tabique dwelling in Trás-os-Montes e Alto Douro region, in 12th International Conference on Durability of Building Materials and Components. Porto: FEUP, pp. 729-736.

[12] Cardoso R. and Pinto J. (2015). Tabique walls composite earth based material characterization in the Alto Douro Wine Region, Portugal. Constructii Journal of Civil Engineering Research, vol. 16, issue 2.

[13] Cardoso R., Paiva A., Pinto J., et al (2016). Characterization of tabique wall nails of the Alto Douro Wine Region. Open Engineering, vol. 6, issue 11, pp.446-454.

[14] Cardoso R., Pinto J., Paiva A., et al (2017). Earth-based material field tests characterization in The Alto Douro Region. Open Engineering, vol. 7, issue 1, pp.435443.

[15] Moatassem A., Boateng A., and Khaled E. (2018). Maximizing sustainability of existing buildings within limited upgrade budgets. Canadian Journal of Civil Engineering, vol. 45 , issue 9 , pp. $705-716$.

[16] Cardoso R., Paiva A., Pinto J, et al (2018). Structural and Material Characterization of a Haussmann Building. Urbanism. Architecture. Constructions, vol. 9, issue 4, pp.347-356.

[17] Cardoso R., Paiva A., Pinto J, et al (2019). Structural and Material Characterization of a Haussmann Building Complex at La Madeleine, Paris. The First Step Before 
Sustainable Rehabilitation and Strengthening. Journal WSEAS Transactions on Environment and Development, vol. 5, issue 2, pp.14-21.

[18] Cardoso R. (2018). Haussmann Structural Floors Repairs and Strengthening Techniques. KTU - Journal of Sustainable Architecture and Civil Engineering, vol. 23, issue 2, pp.16-24.

[19] Biscaia H.C., Chastre C., Cruz D., et al (2017). Flexural strengthening of old timber floors with laminated carbon fiber-reinforced polymers. Journal of Composites for Construction, vol. 21 , issue 1.

[20] CEN, EN 1991-1-1. Eurocode 1: Action on structures - Part 1-1: General actions Densities, Self-weight, imposed loads for buildings. Brussels, 2002.

[21] Pryke J.F.S. (1983). Repair and renewal of buildings. Underpinning, framing, jackingup and moving brick and stone masonry structures. ICE Journal Publishing, pp.47-62.

[22] Cardoso R. (2018). Paris Haussmann Building Underpinning, a study case. Acta Technica Napocensis: Civil Engineering \& Architecture, vol 61, issue 2, pp.40-49.

[23] Rogers R. C. (2000). Modifying Existing Foundations to Carry Additional Load. Practice Periodical on Structural Design and Construction, vol. 5, issue 3, pp.115-121.

[24] Bullivant R.A. and Bradbury H.W. (1996).Underpinning: A Practical Guide. Oxford: Blackwell Science. 